\title{
The Educational Pursuits and Obstacles for Urban Refugee Students in Kenya
}

\author{
Lucy Karanja
}

\begin{abstract}
The Sudanese refugee children in Nairobi, Kenya, face xenophobia and discriminative urban refugee policies, which preclude their admission into public elementary schools in the city. In turn, these children's enrolment in private schools in Nairobi is hindered by their parents' or guardians' precarious socio-economic status. To enhance educational access for their children, a Sudanese refugee community in Nairobi established a school for their children, despite their economic deprivation. Thus, the current study investigated the educational experiences of the Sudanese refugee children at the Sudanese community school, by probing the multifaceted factors that produce and shape those experiences. The study's findings show that the community school provides many Sudanese children in Nairobi with an opportunity to access education, and a welcoming and secure learning environment. However, poor school conditions and inadequate resources preclude the provision of high quality education. Additionally, the students' deprived livelihoods in the city hamper their achievement to their fullest potential. Collaboration between the UNHCR, Kenyan government, and the urban Sudanese refugee community has the potential to improve these students' learning conditions, and their future lives.
\end{abstract}

Key words: urban refugees; urban refugee education; refugee educational settings

\section{Introduction}

Kenya has hosted refugees from war-torn African countries for more than four decades. The numbers of refugees seeking asylum in Kenya increased gradually, with a significant increase in 1992 when refugees totaled approximately 427,000 [1]. This number overwhelmed the Kenyan government's capacity to admit and manage refugees, forcing the government to hand over the refugee status determining responsibility to the United Nations High Commissioner for Refugees (UNHCR). In addition, the government introduced an encampment policy, which requires all refugees to reside in the refugee camps until a suitable solution is available for them [2]. Numbers of refugees in Kenya have dropped since 1993 owing to voluntary repatriation and resettlement. However, there were close to
250, 000 refugees in Kenya by 2005, with the Sudanese comprising the second largest refugee population in the country [3].

Inadequate humanitarian assistance and educational opportunities in refugee camps in Kenya have resulted in an increase in the number of refugees leaving the camps and settling in Nairobi, Kenya's capital city. By moving to the city, these refugees hope to improve their livelihoods and find alternative educational settings where their children can have more access and improved quality education. To many of these refugees, their children's education is a means for a promising future, whether in their home countries or for integration in their countries of asylum. Indeed, the refugees view a well-educated population to be critical in rebuilding their countries both economically and socially [4].

However, instead of fulfilling their aspirations in Nairobi, urban refugees suffer harassment, xenophobia, discrimination, exploitation and poverty [5]. These challenges have resulted in deprived livelihoods and limited access to basic social services, including education for refugee children and youth. Despite the growing body of research on the precarious existence and survival mechanisms of urban refugees in Kenya and other African countries, there is a paucity of research on the impact and implications of urban refugees' legal status and livelihoods on the educational provision and support for their children in urban spaces in countries of asylum.

Consequently, this study investigated the educational experiences of urban Sudanese refugee children at a Sudanese community school (hereafter referred to as Baraka school [a pseudonym]), established by a Sudanese community in Nairobi, Kenya. I argue that the Sudanese community's livelihoods and identities in an urban setting influence their children's educational experiences at Baraka school. Thus, this study examined both school and home factors that shape Sudanese children's educational experiences.

\section{Background}

Despite recent efforts to expand educational access to refugee children, primary education remains inaccessible to many of them in Nairobi. In 
various ways, some Kenyan government policy constrains refugee children's access to education in Nairobi. In the city council primary schools, refugee parents and guardians are required to produce a proper registration document such as UNHCR mandate certificate in addition to the child's birth certificate. Although many refugee children in Nairobi are born in Kenya, they do not have birth certificates, which hinder their enrolment into public schools in Nairobi. However, proper documentation does not necessarily guarantee access to education by urban refugee children. Other barriers, such as discrimination and extortion, have prevented the enrolment of refugee children in some city public primary schools [6]).

Although Kenya introduced free primary education in 2003 providing for the enrolment of refugee children into public schools, many urban refugees are not aware of this opportunity, or lack the capacity to benefit from it [7]). The introduction of free primary education in Kenya has also increased the numbers of Kenyan children accessing education, resulting in limited spaces, resources and infrastructure, and deterioration quality of education. Some school administrators refuse to enroll refugee children in order to preserve spaces for Kenyan children.

Like Kenyan parents, refugee parents and guardians whose children access free primary education must shoulder the burden of providing school-related materials including notebooks, textbooks, uniforms, and, in some cases, a desk for one's child. The precarious economic situations of refugees in Nairobi make it difficult for many of them to support their children education, even when access is available [8].

Refugee children from all groups face somewhat similar educational access and support challenges in Nairobi. However, Sudanese children face more barriers in getting adequate support for their education. Somali, Ethiopian, and Congolese refugees are entrepreneurs and have managed to engage in businesses in the informal economy in Nairobi, which makes survival slightly bearable [9]. On the contrary, many Sudanese do not perceive themselves as entrepreneurs. Instead, their priority is to acquire an education, which they view as instrumental to self-development. This has left the Sudanese refugees more vulnerable to economic hardships in the city, limiting the support they provide for their children's education.

Despite evidence of the deplorable socioeconomic status of urban refugees in Kenya, little research has focused specifically on the educational needs and experiences of their children, and ways in which their livelihoods in an urban setting shape those experiences. Research on the problems affecting Sudanese refugee children's education is, in particular, lacking not only in African cities but also in western countries of refugee resettlement including the U.S.A., Australia, and the UK. In Africa, Moro's [10] and Grabska's [11] studies in Cairo, Egypt, are examples of the few studies that have examined educational issues of Sudanese refugee children in relation to their parents' or guardians' legal and socio-economic status and survival mechanisms. These studies revealed that lack of legal documents and economic hardships of Sudanese refugees were the biggest obstacles to enrolling and maintaining their children in schools. The few studies that have examined and documented the challenges that Sudanese students face in their schooling in the U.S.A, Australia, and the UK [12, $13,14]$, respectively, underscore the importance of nurturing school environments and parental support in promoting the academic well-being of Sudanese refugee children.

In the Kenyan context, issues pertaining to the education of Sudanese refugee children in Nairobi have been reported as vignettes amidst information on other services essential to refugees [15]. This has prevented an in-depth exploration of the concerns facing the education of urban refugee children. Thus, there is a need for more studies into the educational challenges and needs of Sudanese and other refugee children to enable the development of responses and interventions to their problems.

Urban refugees establish self-help schools for their children when faced with limited opportunities or difficulties in enrolling their children into public or private schools. Sudanese refugees have, particularly, been found to actively find educational solutions in urban spaces, especially through creating their own schools in which to educate their children [16]. Thus, this study focused on Baraka school, which is a self-help Sudanese school in Nairobi. The main aim of this study was to acquire a deeper understanding of the educational needs and experiences of the urban Sudanese children, as they have been influenced by their school conditions and livelihoods in Nairobi.

\subsection{Guiding questions and objectives}

The following key question guided this research: What are the educational experiences of urban Sudanese refugee children at Baraka school in Nairobi? Probing questions that teased out the various factors affecting the children's education included: What is the role of Baraka school in the lives of urban Sudanese refugee children in Nairobi? What is the nature of education at Baraka school? How do the livelihoods of the Sudanese refugee children in Nairobi influence their educational experiences?

This study's objectives were to:

1. Describe Baraka school's conditions and resources and examine ways in which they 
promote or hinder effective learning by the Sudanese refugee children.

2. Examine the children's home situations and their implications for their education.

3. Determine the educational needs and challenges of Sudanese refugee children and suggest sustainable school-based interventions and strategies for improving their conditions in Nairobi.

\section{Context: Baraka School}

Baraka school was established by a Sudanese refugee community in Nairobi, who had moved from refugee camps in Kenya in search for better livelihoods as well as education opportunities. The school was started in response to the limited educational opportunities for Sudanese refugee children in public and private schools in Nairobi. In addition, the Sudanese community hoped that the school would give their children a sense of belonging and community, and enable them to maintain their culture. This Sudanese refugee community envisions educating their children as preparing them to return to Sudan to rebuild the country.

The school has an estimated population of 300 students, a few of whom are Kenyan nationals, a gesture that serves to enhance the school's relationship with the local community. The school is impoverished, with small corrugated iron sheeting rooms serving as classrooms. Teachers, resources, and facilities are in adequate. Because of its status as community self-help establishment, Baraka school is registered with the Ministry of Gender, Children and Social Development (MGCSD) in Kenya as opposed to the Ministry of Education, Science and Technology (MOEST). However, the school follows the Kenyan national education system and curriculum.

Baraka school receives no funding from either the Kenyan government or the UNHCR and depends on donors to meet its operating costs. Initially, no school fees were charged to students at Baraka school. However, soaring costs of living in Nairobi and insufficient donor funding has compelled the school to charge a fee of Kenya Shillings (KSh.) 150 (approximately C\$2.50) per student each term. This is in addition to the cost of school uniforms and other supplies that the students' parents/guardians have to meet. These expenses lay a heavy economic burden on the students and their guardians and/or parents.

\section{The Research}

The following sub-sections provide an overview of this study's investigational framework including theories and methods.

\subsection{Theoretical frameworks}

This research is grounded in two complementary theoretical frameworks, namely, critical education theories and postcolonial theories. These theories critically examine ways in which power plays out in social and institutional contexts to oppress the other, resulting in inequalities and injustices for such groups. Based on the premise that the urban Sudanese refugee children are an oppressed and marginalized group, critical education theoretical views [17] were useful in examining the multidimensional issues facing the education of Sudanese refugee children not only from the internal politics of schooling, but also from the wider social and historical positioning of schooling.

With a focus on challenging and resisting dominant views that entrench (post)colonial ideas, coding, and rigid views of the other, postcolonial theory [18] was useful in revealing the hegemonic, essentialist, and stereotypical views of the UNHCR, Kenyan government and the local community towards the Sudanese refugees in Nairobi. As is a common practice in many refugee-hosting countries, the UNHCR and the Kenyan government constructed and produced the urban Sudanese refuges in this study as "marginal and lacking", and held the popular perception of urban refugees as passive, dependent, and economic burdens to the host country [19]. These perceptions result in discriminative urban refugee policies, which deny urban refugees their rights to various social services, including education for their children. Because these refugees are prevented from securing jobs and obtaining work permits, they persist in poverty, resulting in impoverished school and home conditions for their children.

\subsection{Methodology and methods}

This research employed qualitative methods for data collection and analysis. The guiding qualitative principles, data sources, collection strategies, and analysis are explained below.

\subsubsection{Ethnographic case study}

This study is situated within the qualitative interpretive philosophy, which emphasizes the understanding and interpretation of people's meanings of their actions within the system of meaning to which those actions belong [20]. Thus, this study utilizes ethnographic case study methodology and methods as appropriate approaches that provide access to the meanings that guide the participants' behavior [21]. Additionally, the ethnographic case study approaches allowed me as the researcher to investigate and attain some understanding and provide rich descriptions of the Sudanese refugee children's identities, beliefs, 
values, and attitudes, and their unique educational experiences at Baraka school.

\subsubsection{Participants}

Eighteen participants were interviewed including 11 students, 2 teachers, 1parent, 3 guardians, and a UNHCR representative. Because only the student participants' information will be reported in this paper, I will not provide other participants' information. Student interviewees included four females and seven males between 14 to 20 years old and in elementary grades six, seven, and eight. Apart from one female student who was born at the refugee camp, the other students moved to the camp between ages 4 and 14. All but one male student left the Sudan without their families while the female students went to the refugee camp in the company of relatives.

The students stayed at a refugee camp for a period ranging from one to 11 years, where they attended primary schools at various grades. Except the student who was born at the refugee camp, all the others attended school sporadically owing to inadequate educational opportunities at the camp, lack of documentation at the camp, frequent movements from the refugee camp to other countries or parts of Kenya en route to Nairobi, and lack of accommodation once outside the refugee camp. Ten of the 11 students interviewed were old for their grade levels, and, indeed, elementary school, which is an indication of disrupted education and gaps in their schooling as they transited from the Sudan to Nairobi. Additionally, some of them have no families or relatives in Nairobi, keeping them out of school for intervals of time as they seek accommodation. By the time of our interviews, these students had been attending Baraka school for an average of $1 \frac{1}{2}$ years.

\subsubsection{Data collection and analysis}

Consistent with the ethnographic case study approaches, I stayed at Baraka school for four months and collected data through multiple methods namely; semi-structured interviews, participant observation, and document analysis. Each student was interviewed in one session lasting between 30 to 60 minutes. All interviews took place over several Saturdays at the school, as many of the students attend school on Saturdays for private or group studying. The interviews were audio-taped and field notes were taken.

I applied an inductive thematic analysis approach in order to discover overarching themes that emerged from my participants' data, as well as from the observations and documents. This analysis was achieved by following Lincoln and Guba's [22] three analytical steps namely; unitizing textual data into idea units, coding categories, and integrating categories. This process resulted in five overarching themes, which are discussed below. These include:
Students' positive school experiences; Education at the school; Students' challenges; Resilience, and Support challenges.

\section{Results}

This study's findings show that the educational experiences of urban Sudanese refugee children comprised challenges and opportunities. The challenges resulted mainly from their precarious livelihoods in the city, especially because many of them were without parents or relatives to provide for their needs. The opportunities derived from Baraka school as a place where the students accessed education, which they hoped would lead to a bright future. The students' positive school experiences, school- and home-related shortcomings, and their coping strategy are discussed here.

\subsection{Positive school experiences}

From the testimonials of participants in this study, Baraka school has provided educational access to many Sudanese children in Nairobi, who might have difficulties accessing other educational settings such as public or private schools. Student participants unanimously described Baraka school and its general atmosphere as positively impacting their social and educational lives. Student A pointed out that "If there is no school here for the refugees, it will be very difficult for the refugees to be in the Kenyan schools.” Student B reiterated the school's importance by stating that, "[Baraka] is wonderful because many of us were not in school when it was not there but nowadays many [Sudanese] kids are in school".

The students observed that Baraka school provided an educational opportunity to poor Sudanese children, who could not afford the high fees and many supplies required in public schools in Nairobi. Student C's remark is representative of the other students' views regarding the relative affordability at Baraka school: "It is good here because if you go to government school they would just allow those who can afford the fees that they charge and the things they want. But here, they do not charge a lot of money for school fees.” Factors such as the Sudanese students' advanced age and their legal status in the city prevented their admission into public schools in Nairobi. In Baraka school, however, they were admitted unconditionally and they did not face discrimination either during admission or in form of unfair treatment in the school, which they experienced in some public schools.

Baraka school also acted as a safety net for the students, offering them a sense of security and belonging. The students expressed a sense of safety in being among other students, and some teachers, with whom they shared the same culture and language. A shared language between the students 
and some teachers not only fostered communication among them but also facilitated learning course content. Student D noted that: "[At Baraka], if I don't understand something in English, the teacher will explain to me in Kiswahili. If I don't understand it in Kiswahili then the teacher will explain to me in my mother tongue." The use of students' native languages also allowed parents and guardians to attend school conferences and, using their native languages with translation, discuss school matters, and advise their children regarding good behaviors and study practices.

At Baraka school, the students' needs and shortcomings were understood and accommodated by the school administration. Students were not sent home for wearing non-uniforms to school, failing to pay school fees on time, or for lack of required school supplies. Instead, the school made attempts at supporting the students by allowing them time to pay school fees, and buying a few text books that students could borrow to use at home. Cognizant of the difficulties that these students had in securing basic needs, the school also provided lunch everyday to the students. For many of these students, this was the only meal for the day as indicated by Student E: "Sometimes you go home and there is no food. It becomes frustrating. If there is no food in school, then I will not have any food for the day.”

\subsection{Education at Baraka school}

This theme related to the kind of curriculum and pedagogical strategies employed at the school. Students interviewed in this study praised the Kenyan curriculum of education used at Baraka school. They expressed satisfaction that the curriculum - its content and range of subjects- was not only meeting their present educational needs but would enable them to meet their future goals. However, a further analysis of these participants' views using critical education theories and literature on curriculum relevance revealed that the curriculum used at Baraka school fell short of meeting present and future needs of the Sudanese refugee children adequately. This curriculum lacks components that would address the special needs of refugee children such as psychosocial needs and practical knowledge and survival skills, which are necessary for children suffering the effects of war and displacement.

Regarding teaching and learning procedures at the school, I observed that to a large extent, teachers used whole-class, teacher-centered methods, with minimal teacher-students and student-student interactions. Teacher-student interactions were limited mainly to the teacher asking questions and the students providing answers. In addition, teachers did not use teaching aids to enhance their lessons. The classroom walls were bare; visuals such as charts, maps, and drawings were conspicuously absent. Consequently, students learned mainly through rote memorization, and their creativity and critical thought were stifled.

However, student participants in this study were oblivious of the negative effects of the pedagogical strategies at the school. These students evaluated good teaching based on whether teachers attended class or not, and on their availability to answer their questions and provide other educational help that they needed. Students F commented: “The teachers here teach well. They make sure they attend class to teach." Student G added that, "Teachers come to class. They teach us well and answer our questions. They are committed to helping us even after school hours." Although a few students expressed a different opinion regarding teachers' class attendance, they still used class attendance as a measure of good teaching. According to student $\mathrm{H}$, "Teaching is not good this year. Some teachers can stay without coming to class to teach so that makes one to be discouraged. If teachers can come [to class] always, that can make you to know more.” Clearly the students uncritically perceived teachers as sources of knowledge and they as recipients of this knowledge.

\subsection{Challenges at Baraka school}

Despite the general atmosphere at Baraka school being supportive of students' learning, the students identified school's location next to a main road as exposing them to safety risks. As the students observed, vehicles had occasionally veered off the road and narrowly missed hitting students playing or walking by the school. The school is also located near a landfill, which is a potential health hazard to the students. As one student remarked, "When it rains water mixed with dirty materials from the dump comes inside the classrooms." Additionally, the students reported that the school structures, which are made of iron sheeting, made the classrooms to be very hot during hot weather and cold in cold weather. These extreme conditions made the students uncomfortable in the classrooms, adversely effecting their concentration.

Other problems included a shortage of teachers and educational facilities such as textbooks and a library. In many of the classrooms at Baraka school, the teacher was the only person with a copy of the textbook for the course he or she was teaching. Consequently, the students observed that it was difficult for them to do independent or extra studying at home or to complete homework. In most cases, teachers wrote assignments on the chalkboard and the students copied it in their note books, an exercise that reduced the teaching time allocated for the lesson.

The students found the lack of extra-curricular facilities such as sports and games equipment to be disappointing, especially because many of them were quite active in sports. Student $\mathrm{J}$ depicted the 
students' frustration from a lack of these facilities: "People here are good in sports but we do not even have a playground. We like to play matches with other schools..., [but] we do not even have balls, sports uniforms, and nets for playing." Although these students often times won matches with other schools, they indicated that they would perform even better if they had the necessary facilities, which would boost the school's esteem.

Living in the city without adequate and stable provision presented the students with difficulties. While some students lived with close relatives, others, especially the males, lived with other students, or with guardians with whom they were not related. The students reported that they relied on their parents, other relatives or friends in Sudan, Kenya or in western countries for provision of basic needs and school fees and supplies. Such provision was not always guaranteed even for students who lived with parents, due to the precarious economic situations of their benefactors, whether in Nairobi, back in the Sudan, or in western countries. Student K and his brother's experiences are typical of many of the students attending Baraka school, "We have our father who is in Sudan so sometimes he tries to send a little money. Sometimes there is no money. For example, we have five months where we have no money so we just survive like that." Consequently, students reported that they were constantly anxious over how to obtain school fees and other supplies, rent money, and even food and shelter. For some, this anxiety impacted on their concentration on their school work.

Because of financial strain, almost all the student interviewees indicated that they walked long distances to and from school, leaving them tired through the day and when they returned home. From the students' reports, these problems affected their school attendance; some attended school irregularly due to lack of provision of one kind or other.

\subsection{Resilience}

The student participants expressed ambivalence about their existence in Nairobi with no provision from the UNHCR or the Kenyan government. However, they were hopeful that education would pave way for a bright future. These student developed resilience as a psychological tool to help them cope with the stress they experienced as a result of lack of stable livelihoods and provisions, and inadequate facilities at school. Although the participants pointed out the various things that they thought were problematic at Baraka school, they did not want to be fixated on those problems as hindrances to their education. At least, these participants tolerated these problems for the sake of education. Student L, for example refused to let the problems at school prevent her from working toward her goal of succeeding in school: "I don't see problems because I have been in critical conditions when I was very young but now as long as I get an education I am fine.” Student A added that despite the hardships in Nairobi, he was persevering for the sake of education: "Things are hard in Nairobi but when you are looking for something it is better to struggle so that you can gain something. We are just trying to survive."

By adopting resilience as a coping strategy, the students in this study were hopeful that circumstances, especially in the school, would improve gradually. They did not want to demand changes, thereby losing their educational vision. Although they would appreciate improvements in the school, they were ready to wait for a time when that would be possible, as indicated by student C: "It is not a must [to have changes]. If there is help then I would like to see the changes but if not then it is okay. It can take time for the donors to get some money." Student G reiterated this patience in improvements at the school: "I have seen other schools like the City Council ones. They are good and it would be good if they did this one like that but... maybe one time they will do it like that. Things cannot be done at once.” Undoubtedly, these students exhibited tolerance for the situations that they faced, and appreciation for having Baraka school as a place from which to gain education.

\subsection{Support challenges and opportunities}

Interview data from student participants revealed that the Sudanese community supported the Sudanese children's education partially, providing mainly advice, school fees and other supplies, and needs at home such as accommodation and food, albeit with difficulties. Refugee-ship and urban living complicated livelihoods for the Sudanese refugee community in this study, presenting challenges in their efforts to support their children's education at Baraka school. The students interviewed in this study were aware of their parents' and community's deprived situation in the city, hence, their limitation in supporting their education beyond providing school supplies. As student J commented, "The parents have no power [to provide a lot of support] because they are foreigners and they are in the city so they don't have enough to help."

Unemployment in the city prevented parents and guardians of the students from paying for school improvements such as better structures and facilities or even re-locating the school to a more secure site. The students observed the difficulties experienced by their parents and guardians in obtaining work permit or even engaging in other income-generating activities. Additionally, many of the parents and guardians struggled to support their children's education single-handedly, some of them as single mothers with husbands either deceased or back in the Sudan with little or no support for the families in 
Nairobi. For example, two student interviewees indicated that they lived with their mothers in Nairobi while their fathers were in the Sudan, with little support and communication from them. Generally, students expressed a sense of helplessness regarding obtaining adequate support for their education.

With no exception, student participants in this study stated that the responsibility of making major school improvements-better buildings, library facilities, and equipment for extra-curricular activities-rested with a donor organization that provides funds towards the school's operating budget. According to them, the school would close if the donor organization cut off its support to the school. One student remarked that, "When the donors don't have money, I think there will be no school... it will close down." Although the donor organization continually provided funds for minor school improvements and repairs, other more costly developments in the school had not been addressed due to lack of funds. Hence, the school's poor conditions and inadequate resources have persisted.

Participants in this study did not expect the UNHCR to support the school in any way, despite its mandate to care and provide for refugees. The students held to the mistaken believe that the UNHCR provided assistance to refugees in camps only. Hence, they should go back to the camps if they needed UNHCR provision. The students' views were summarized by student B in his statement that, "I don't think [the UNHCR] can help. This is an urban center. The UNHCR requires refugees to stay in the camp.... They assume that the person who moves to the city has money." Clearly, these students were not aware of some new UNHCR initiatives aimed at supporting urban refugees to be economically independent. For example, on two different occasions, the school had received some material support through micro-grants provided by UNHCR to refugee self-help groups. Such assistance suggests that the school might receive continuous support from the UNHCR if the refugee community petitions for it.

\section{Discussion and Recommendations}

The problems facing the education of urban Sudanese refugee children in this study will have negative influence on their future survival, that of their communities, and their host country, Kenya.

\subsection{Educational curriculum}

The Kenyan curriculum of education utilized at Baraka school benefits Sudanese students by providing them with basic competencies namely, reading, writing, and numeracy, which would enable them to pursue learning. The curriculum also provides academic knowledge in various subjects such as science, which they can apply in dealing with aspects of their lives to include the need for proper nutrition, clean water, and sanitation, among others.

However, this curriculum is mainly academic and largely theoretical, with little emphasis on practical knowledge and survival skills that are critical for the survival of urban Sudanese refugee children. By utilizing an academic-oriented curriculum, the assumption seems to be that all students will progress along academic lines, and build careers requiring academic courses. However, based on the financial constraints facing many of the Sudanese students at Baraka school, it is evident that some of them may not pursue secondary education and, if fortunate, may pursue various trades. Without a curriculum that provides some life skills and vocational training, these students might graduate from primary school with few survival skills, which are critical for them whether in Kenya or back in the Sudan.

Sinclair [23] differentiates between curricula for students in displaced and refugee situations, and for others not facing such situations. She observes that the educational curriculum for the former group of students gives priority to, "[basic] learning and basic knowledge for coping mentally and physically....along with knowledge and practice that will help promote a peaceful and values-/rightsbased rebuilding of the war-torn communities (p. 2)." Clearly, the traditional subject-focused Kenyan curriculum of education does not address those issues for these Sudanese refugee children.

In order to make the curriculum relevant to the urban refugee student's needs, it should be enriched with knowledge, skills, and messages that will facilitate current and future functioning and survival of these children. The school can provide students with practical knowledge and skills through basic vocational training in areas such as agriculture, carpentry, tailoring, and other skills in family studies, which students who cannot afford to continue their education can use to earn a living. Adding other life skills and values education through programs such as health and nutrition, peace education, human rights, and environmental awareness would enrich the students' lives while at school and the lives of their community members thereafter.

Accommodating the teaching of these skills and messages into the teaching of normal subjects can be difficult, especially given resource and teacher constraints, and an overloaded curriculum. However, the school can set aside time after school, during school holidays and study circles to teach these knowledge and skills.

\subsection{Pedagogical practices}

The predominantly traditional teaching styles used by teachers at Baraka school resulted in banking education, which critical education theorists 
have criticized for disempowering students. Such an education not only prevents students' active participation in their learning but also presents a limited view of education's transformative potential through the denial of critical thinking skills, which are essential for the improvement of the students' academic and future lives.

In teacher-dominated classrooms such those at Baraka school, knowledge that is supposed to empower students to engage as subjects in their world is reduced to information provided to the students by the teacher [24]). Indeed, teachers adopting the teacher-centered teaching strategies consider information to constitute true knowledge. This view of knowledge serves to de-humanize students and reduce them to objects in their world. They become passive in the pursuit for true knowledge that would be useful in resisting and challenging the oppressive forces that they face.

Because different students have varied learning styles, teachers should present information in a variety of modes in order to meet the multiple learning styles of students in the classroom [25]. Effective instructional strategies are essential for the urban Sudanese students' current and lifelong successful learning. Consequently the following improved methods are suggested: (i) use of visual aids and experiential learning. These include low- or no-cost teaching aids such as pictures/images, diagrams, maps, and charts; (ii) cooperative learning to include pair and small group activities; (iii) peer tutoring, which may involve one-on-one tutoring, class-wide reciprocal peer tutoring, or cross-age tutoring [26]; (iv) authentic teacher-student discourse including authentic teacher questions, and dialogic instructional discourses such as whole class discussions and activities, student demonstrations, journals, and learning logs [27].

\subsection{Educational support}

Although the donor organization and the urban Sudanese refugees' parents and guardians support Baraka school students, additional support towards improving the school's facilities and providing more teachers and resources is critical. Improved educational support for the Sudanese refugee children at Baraka school has the potential to not only enhance their academic achievements, but also to produce well-adjusted people who are ready to take up their responsibilities in Sudan, Kenya, or wherever they may choose to live. Failing to adequately support the education of these refugee children will hamper their future plans and make them a burden to the struggling Kenyan economy.

Hence, several suggestions might help to better meet the educational needs of the refugee children in this study better. The Kenyan government should provide financial support to Baraka school proportional to the number of Kenyan students enrolled at the school. Also, the UNHCR should take more responsibility in supporting Baraka school, especially because it serves refugee children. Additionally, the urban Sudanese refugee community should organize a lobby group that would petition the Kenyan government for funds that are available to public schools in Nairobi. Finally, the refugee community can organize fundraisers towards identified school projects such as buying text books and providing equipment for extra-curricular activities. The community can also solicit for material donations from commercial businesses, publishers, and charitable organizations.

\section{Conclusion}

The focus of this paper is the educational experiences of Sudanese refugee children in a school established by their community. By focusing on this school, this paper goes beyond the already documented educational access problems of urban refugee children to provide insights into the actual conditions under which Sudanese refugee children in Nairobi get educated, and the quality of education that those conditions produce. As demonstrated in this paper, the urban Sudanese refugee children in this study are getting educated under impoverished conditions. These conditions have resulted in low quality education, which may be of questionable effectiveness in facilitating these children's pursuit of higher education and building careers for which they aspire. The Sudanese refugee community's efforts to support their children's education are thwarted by their deprived livelihoods and other socio-political factors, which prevent them from engaging in economic activities in order to improve their livelihoods. However, the community's commitment to support their children's education, albeit with difficulties, is a powerful message to the host government and the UNHCR about the importance of educating refugee children, and the need to support that endeavor.

Therefore, this paper underscores the importance of educating refugee children effectively, to enable them re-build their country, or make positive contributions in any other country where they may settle. Hence, collaborative efforts of all stakeholders in the education of these children are critical in providing an education that liberates them from socio-economic and political oppression.

\section{References}

[1] Loescher, G. \& Milner, J. (2005). Protracted refugee situations: Domestic and international security implications. New York: Routledge.

[2] Verdirame, G. (1999). Human rights and refugees: The case of Kenya. Journal of Refugee Studies, 12, 54-77.

[3] UNHCR (2007). 2005 UNHCR statistical yearbook country data sheet - Kenya. Retrieved from 
http://www.unhcr.org/4641be610.pdf (Access Date: 15 September, 2009).

[4] Dryden-Peterson, S. (2004). Educating refugees in countries of first asylum: The case of Uganda. Migration Information Source. Retrieved from http://www.migrationinformation.org/Feature/display.cfm? ID=220 (Access Date: 20 October, 2006).

[5] Campbell, E. (2006). Urban refugees in Nairobi: Problems of protection, mechanisms of survival, and possibilities for integration. Journal of Refugee Studies, 19, 396-413.

[6] Jacobsen, K. (2005). The economic life of refugees. Bloomfield, CT: Kumarian Press

[7] Pavanello, S., Elhawary, S., \& Pantuliano, A. (2010). Humanitarian Policy Group Working Paper. Oversees Development Institute

[8] Wagacha, J. \& Guiney, J. (2008). The plight of urban refugees in Nairobi, Kenya. In D. Hollenbach (Ed.), Refugee rights: Ethics, advocacy, and Africa (pp. 91-102). Washington, D.C.: Georgetown University Press.

[9] Campbell, E., Kakusu, J., \& Musyemi, I. (2006). Congolese refugee livelihoods in Nairobi and prospects of legal, local integration. Refugee Survey Quarterly, 25, 93 108.

[10] Moro, L. (2002). Refugee education in a changing global climate: The case of Sudanese in Egypt. A paper presented at the $46^{\text {th }}$ Annual Meeting of Comparative and International Education Society (CIES), March 6-9, 2002, Orlando, FL: ERIC Document Reproduction Service No. ED479095

[11] Grabska, K. (2006). Marginalization in urban spaces of global south: Urban refugees in Cairo. Journal of Refugee Studies, 19, 287-307.

[12] Walker-Dalhouse, D., \& Dalhouse, A. (2009). When two elephants fight the grass suffers: Parents and teachers working together to support the literacy development of Sudanese youth. Teaching and Teacher Education, 25, 328-335.

[13] Brown, J., Miller, J. \& Mitchell, J. (2006). Interrupted schooling and the acquisition of literacy: Experiences of Sudanese refugees in Victorian secondary schools. Australian Journal of Language and Literacy, 29, 150-162

[14] Rutter, J. (2006). Refugee children in the UK. New York, NY: Open University Press

[15] UNHCR, Nairobi (2007). Report of the participatory assessment. Theme: Urban refugee community structures. UNHCR Branch Office Nairobi, October 2007: Internal Document

[16] Dryden-Peterson, S. (2003). Education of refugees in Uganda: Relationship between setting and access. Refugee Law Project Working Paper No. 9. Retrieved from http://www.refugeelawproject.org/resources/papers/workin gpapers.index.htm (Access Date: 1 March, 2007).

[17] Freire, P. (1993). Pedagogy of the oppressed. New York, NY: Seabury Press.

[18] Bhabha, H. (1994). The location of culture. New York, NY: Routledge.
[19] Turner, S. (2004). Under the gaze of the 'big nations': Refugees, rumours and the international community in Tanzania. African Affairs, 103, 227-247

[20] Schwandt, T. (2000). Three epistemological stances for qualitative inquiry: Interpretivism, hermeneutics, and social constructivism. In N. Denzin \& Y. Lincoln (Eds.), Handbook of qualitative research ( $2^{\text {nd }}$ ed.) (pp. 189-213). Thousand Oaks, CA: Sage.

[21] Hammersley, M. \& Atkinson, P. (1995). Ethnography: Principles in practice ( $2^{\text {nd }}$ ed.). New York, NY: Routledge.

[22] Lincoln, Y., \& Guba, E. (1985). Naturalistic inquiry. Newbury Park, CA: Sage.

[23] Sinclair, M. (2001). Education in emergencies. In J. Crisp, C. Talbot, \& D. Cipollone (Eds.) Learning for a Future: Refugee Education in Developing Countries, (pp. 1-83). UNHCR, Geneva. Retrieved from, http://www.unhcr.org/pubs/epau/learningfuture/ch01.pdf (Access Date: 30 May, 2009).

[24] Hooks, B. (1994). Teaching to transgress: Education as the practice of freedom. New York, NY: Routledge

[225] Felder, R., \& Henriques, E. (1995). Learning and teaching styles in foreign and second language education. Foreign Language Annals, 28, 21-31.

[26] Robinson, D., Schofield, J., \& Steers-Wentzell, K. (2005). Peer and cross-age tutoring in math: Outcomes and their design implications. Educational Psychology Review, 17, 327-362.

[27] Nystrand, M., \& Gamoran, A. (1997). The big picture: Language and learning in hundreds of English lessons. In M. Nystrand, with A. Gamoran, R. Kachur, \& C. Prendergast, Opening dialogue: Understanding the dynamics of language learning in the English classroom (pp.30-74). New York, NY: Teachers College Press. 